\title{
The Effect of Organizational Culture, Principal Leadership,and Job Satisfaction to Teachers' Organizational Commitment in The Public Vocational High School of Sibolga City
}

\author{
Jailani Tumanggor ${ }^{1}$ \\ \{* penikmat.demokrasi21@gmail.com \} \\ Medan State University, Medan, Indonesia
}

\begin{abstract}
This study aims to describe and find out: (1) The Effect of Organizational Culture on Job Satisfaction; (2) Effect of Principal Leadership on Job Satisfaction; (3) Effect of Organizational Culture on Organizational Commitment; (4) Effect of Principal Leadership on Organizational Commitment; and (5) Effect of Job Satisfaction on Organizational Commitments of Sibolga City State Vocational Schools. This study uses quantitative methods, the model used is path analysis with analytical and inferential techniques. The population in the study were all teachers of the Sibolga City Vocational School, amounting to 203 teachers. The research sample was determined using proportional random sampling technique so that a sample of 135 teachers was obtained. The research instrument used for data collection was a questionnaire. The results of this study were found: (1) there is a positive direct effect of organizational culture on job satisfaction with a correlation coefficient $\rho=0.18$ with a contribution of $03 \%$; (2) there is a positive direct effect of the principal's leadership on job satisfaction with the correlation coefficient $\rho=0.42$ with a direct influence of $18 \%$; (3) there is a positive direct effect of organizational culture on organizational commitment with a correlation coefficient $p=0.23$ with a contribution of $5 \%$; (4) there is a positive direct effect of the principal's leadership on organizational commitment with a correlation $\rho=0.23$ with a contribution of $5 \%$; and (5) there is a direct effect of positive job satisfaction on organizational commitment with a correlation coefficient $\rho=0.24$ with a contribution of $6 \%$. So, to increase organizational commitment there needs to be an increase in organizational culture, principals' leadership, and job satisfaction.
\end{abstract}

Keywords: Organizational culture, principal leadership, job satisfaction, organizational commitment.

\section{Introduction}

Education is a major factor in supporting the progress of a nation through improving the quality of human resources (HR). A developed nation is a nation that has quality human 
resources. Superior human resources (HR) are requirements for the realization of readiness in facing all developments in the era, including the era of globalization

The quality of education in Indonesia is very low when compared to countries on an international scale. According to [2] Indonesia was ranked third from the bottom in terms of quality education, in 2006 Indonesia ranked 50th out of 57 participating countries. The low quality of Indonesian human resources can also be observed from the low number of the Human Development Index (HDI) which is in the rank of 106 out of 109 countries (Ministry of National Education in Ambarita and Pangaribuan 2013: 86). Furthermore, based on the results of research conducted by Balitbang PDIP in 2008 stated that the percentage of decent teachers in accordance with their profession was as follows: high school teachers $67.1 \%$, junior high school teachers $64.1 \%$, and elementary teachers $50.7 \%$. This marks the average overall teacher, starting from elementary, middle and high school, with an average of $60.3 \%$ not yet professional or not worthy of being a teacher. Therefore, teacher organizational commitment needs to be improved so that the teacher is able to carry out his duties as a teacher well so that the goals of national education can be achieved.

According to [1], schools are educational institutions that are held in a very regular time, a program that is very rich and systemic, carried out by educational staff who are professional in their fields and equipped with adequate facilities. The quality of Indonesian education is currently considered low. Efforts made to achieve educational goals have been the subject of studies by education stakeholders in Indonesia.

Schools as an education system have components that are related to each other and contribute to the achievement of goals. These components are students, curriculum, teaching materials, teachers, principals, other education personnel, environment, facilities, facilities, learning processes and results or outputs. All the components of the course must synergize, change to a better direction and develop in accordance with the demands of the times or changes that occur around it, of course changes in change and development must include all components of the school.

Vocational High School (SMK) is one form of formal education unit that provides vocational education at the secondary education level as a continuation of SMP / MTs or other forms of equivalent or continued learning outcomes that are recognized as equal / equivalent to SMP / MTs. (https://id.wikipedia.org/wiki/Sekolah_menengah_kejuruan-7-4-17-17:11). Vocational High School is one of the levels of secondary education with the specialty of preparing graduates to be ready to work. Vocational education has varied meanings but can be seen as a red thread. With the understanding that each field of study is vocational education as long as the field of study is studied more deeply and the depth is intended as a provision to enter the workforce.

The teacher as a sub-system of the school is the component that most determines how the educational process works and how the educational goals are achieved. Based on the results of studies in developing countries, it has been proven that teachers make the highest contribution in learning achievement (36\%), followed by management (23\%), study time $(22 \%)$, and physical facilities (19\%), delivered by the Director General Dikdasmen at the Open University Anniversary XVI Anniversary. (http://smkn2sibolga.sch.id/pemberdayaan-guru/13-03-2017).

In working the teacher must have a sense of responsibility and high dedication to the work itself and to the work environment. Teachers will work with full responsibility and dedication if they have organizational commitment. [2] says that commitment is the most basic thing for everyone in their profession. The success of a person in a task given to him is determined by how committed they are to the task and the level of education or knowledge. Without a commitment, the tasks given to him are difficult to carry out properly. A high 
commitment to the task becomes a motivation to do with sincerity. Streer in [3] states that organizational commitment is as follows: (1) a strong desire to remain as a particular organization; (2) the desire to strive according to the wishes of the organization; (3) Certain beliefs, and acceptance of organizational values and objectives. In order to realize this many factor, influence it, including organizational culture.

Colquitt, Lepine, and Wetson (2009: 68-69) define that organizational commitment is the desire to remain a member of the organization. So, a teacher who has a high organizational commitment to the school where he works, does not want to leave the school, because he feels that the goal organization in accordance with its objectives, namely the willingness of people to stay with the organization and contribute passionately to achieving goals.

Aron and Greenberg (1990) suggest that the higher the level of responsibility and autonomy given to someone in carrying out work, the more attractive a job is to someone, the higher the commitment. Conversely, the more open opportunities to work in other places, the lower the commitment. The level of satisfaction in the current work has an effect on the level of commitment. Furthermore, the situation of organizational culture is able to raise the level of employee commitment, as well as the attention of the organization to the level of welfare.

Regarding teacher job satisfaction, Davis and Newstrom in Ambarita, Siburian, and Situmorang [5] stated that job satisfaction is defined as someone's feeling of being happy or unfavorable regarding their work. In other words, job satisfaction is a perception of someone or what has been done or done. Job satisfaction will be obtained when there is a match between the expectations of workers with the reality obtained from where they work.

[4] explain that job satisfaction affects performance and organizational commitment. That is, paying attention to job satisfaction is important because it affects a person's performance, where performance determines the achievement of a work goal. In conclusion, teacher job satisfaction can influence the achievement of educational objectives at the school level and ultimately the educational goals nationally. So that the factors or things that affect teacher job satisfaction are very important to note.

Based on the author's observations in the field, through interviews with several teachers from each Sibolga City State Vocational School and several students it was found that there were still teachers who acted only as presenters who had not mastered the material in depth. The process of teaching and learning activities observed by researchers varied, some of which took place effectively and some were lacking, and some were not at all. Things like this appear in different teaching and learning situations, not yet utilizing available teaching time, starting lessons that are not on time, rarely using interactive media, lacking cooperation among fellow teachers, still lacking work motivation. There are also teachers who have been involved in an education and training so that the impact on the teacher feels less satisfied in carrying out their duties and responsibilities. The above situation shows the weak implementation of management, low human resources possessed, organizational culture that has not been oriented to quality, low performance and weak organizational commitment. [4] in his research suggested that the problems experienced by secondary school teachers today are weak organizational commitment.

Marcoulides and Heck in [6] suggest that organizational culture as a concept can be a means to measure the suitability of organizational goals, strategic and organizational tasks, and can be produced. Hofstede in [7] suggests that culture can be defined as various interactions of habitual characteristics that influence groups of people in their environment.

According to[9], another factor considered to be influencing organizational commitment is leadership. Anoraga [8] suggests that there are nine roles of leadership in an organization, namely leaders as planners. Leaders as policymakers, leaders as experts, leaders as executors, 
leaders as controllers, leaders as gift givers or punishments, leaders as role models and symbols or symbols, leaders as places to blame, and leaders as substitutes for other members' roles. Therefore, the dreamer's ability from a leader becomes an important condition. If a leader is right, it can be assumed that the level of teacher organization commitment will also increase.

Teacher job satisfaction determines the formation of organizational commitment. Teacher job satisfaction needs to get serious attention, because job satisfaction allows high levels of dedication to the work done. [9] suggests that job satisfaction is an assessment, feeling or attitude of a person or employee towards his work and is related to the work environment, type of work, compensation, relationships between coworkers, social relations in the workplace and so on. If a teacher is satisfied with what he receives, it will produce high quality and productivity. Conversely, if the teacher does not feel satisfaction in carrying out his duties, then this might cause things that would be detrimental to the school, such as low quality schools, such as low quality of work, lack of discipline in carrying out teaching, often late coming to school, less attention to students those who have problems, look for busyness in other places, do not take seriously in carrying out tasks, are apathetic, and lack initiative to hold innovations in the teaching and learning process.

In general, in Indonesia public schools are still the main choice of the community. Besides quality can still outperform private schools, also the costs needed are relatively less. State Vocational Schools in Sibolga City (State Vocational School 1, State Vocational School 2, and State Vocational School 3) are the main choices for the community of Sibolga City, also Central Tapanuli Regency as their place or their children study, while other State Vocational Schools outside Sibolga are only an escape alternative. That means that State Vocational Schools are the foundation of hope for giving birth to intelligent people according to national education goals.

Based on the explanation above, according to the context of the teacher's role, it is assumed that organizational culture, leadership of the principal, and job satisfaction, have an effect on organizational commitment to teachers of Public Vocational Schools in Sibolga City. This study was designed to test it.

\section{Methodology}

The location of this research is Sibolga City State Vocational School which consists of 3 schools. This research was conducted using quantitative research methods. The model used is the path analysis model. The path model used in this study is a correlation path model, because in this model exogenous correlation is calculated. This study analyzes the influence of one variable on the other variables, namely: (1) organizational culture, (2) principal leadership, (3) job satisfaction, and (4) teacher organizational commitment.

The number of samples was carried out by referring to the Krejcie-Morganyang Table which was chosen proportionally with a confidence level of $95 \%$, for a population of 203 , it obtained a sample of 135 people. Sampling is done by proportional random sampling. 


\section{Result and Discussion}

Based on the results of research on organizational commitment, the mean $=107.97 ; \mathrm{SD}=$ 16.08; Mode $=115.83$; and median $=107.5$.

Table 1. the results of research on organizational commitment

\begin{tabular}{clrrr}
\hline Class & $\begin{array}{c}\text { Class } \\
\text { Interval }\end{array}$ & $\begin{array}{c}\text { Class } \\
\text { Edge }\end{array}$ & $\begin{array}{c}\text { Abs. Freq. } \\
\left(\mathbf{f}_{\text {abs }}\right)\end{array}$ & $\begin{array}{c}\text { Rel. } \\
\text { Freq } \\
(\%)\end{array}$ \\
\hline 1 & $72-79$ & 71.5 & 8 & 5.93 \\
2 & $80-87$ & 79.5 & 13 & 9.63 \\
3 & $88-95$ & 87.5 & 9 & 6.67 \\
4 & $96-103$ & 95.5 & 19 & 14.07 \\
5 & $104-111$ & 103.5 & 19 & 14.07 \\
6 & $112-119$ & 111.5 & 32 & 23.70 \\
7 & $120-127$ & 119.5 & 21 & 15.56 \\
8 & $128-135$ & 127.5 & 14 & 10.37 \\
\hline Sum & & \multicolumn{4}{|c}{} \\
\hline
\end{tabular}

The results of organizational culture research, the mean $=123,2 ; \mathrm{SD}=21,91$; Mode $=$ 133,$65 ;$ and median $=123,19$.

Table 2. The results of organizational culture research

\begin{tabular}{clrrr}
\hline Class & $\begin{array}{c}\text { Class } \\
\text { Interval }\end{array}$ & $\begin{array}{c}\text { Class } \\
\text { Edge }\end{array}$ & $\begin{array}{c}\text { Abs. Freq. } \\
\left(\mathbf{f}_{\text {abs }}\right)\end{array}$ & $\begin{array}{c}\text { Rel. } \\
\text { Freq } \\
(\mathbf{\%})\end{array}$ \\
\hline 1 & $53-63$ & 53.5 & 7 & 5.19 \\
2 & $64-74$ & 63.5 & 7 & 5.19 \\
3 & $75-85$ & 74.5 & 16 & 11.85 \\
4 & $86-96$ & 85.5 & 20 & 14.81 \\
5 & $97-107$ & 96.5 & 21 & 15.56 \\
6 & $108-118$ & 107.5 & 30 & 22.22 \\
7 & $119-129$ & 118.5 & 21 & 15.56 \\
8 & $130-140$ & 129.5 & 13 & 9.63 \\
\hline Sum & & \multicolumn{4}{|c}{} \\
\hline
\end{tabular}

The results of principal leadership, so that mean $=110,17 ; \mathrm{SD}=16,92$; Modus $=115,76$; and median $=110,74$.

Table 3. The results of principal leadership

\begin{tabular}{|c|c|c|c|c|}
\hline Class & $\begin{array}{c}\text { Class } \\
\text { Interval }\end{array}$ & $\begin{array}{l}\text { Class } \\
\text { Edge }\end{array}$ & $\begin{array}{c}\text { Abs. } \\
\text { Freq. } \\
\left(f_{\text {abs }}\right)\end{array}$ & $\begin{array}{c}\text { Rel. } \\
\text { Freq } \\
(\%)\end{array}$ \\
\hline 1 & $61-70$ & 60.5 & 2 & 1.48 \\
\hline 2 & $71-80$ & 70.5 & 8 & 5.93 \\
\hline 3 & $81-90$ & 80.5 & 6 & 4.44 \\
\hline 4 & $91-100$ & 90.5 & 22 & 16.30 \\
\hline 5 & $101-110$ & 100.5 & 20 & 14.81 \\
\hline 6 & $111-120$ & 110.5 & 40 & 29.63 \\
\hline 7 & $121-130$ & 120.5 & 22 & 16.30 \\
\hline 8 & $131-140$ & 130.5 & 15 & 11.11 \\
\hline Sum & & & 135 & $100 \%$ \\
\hline
\end{tabular}

The results of job satisfaction, so that mean $=106,85 ; \mathrm{SD}=16,87$; Modus $=110,56$; and median $=109,43$. 
Table 4. The results of principal leadership

\begin{tabular}{|c|c|c|c|c|}
\hline Class & $\begin{array}{c}\text { Class } \\
\text { Interval }\end{array}$ & $\begin{array}{l}\text { Class } \\
\text { Edge }\end{array}$ & $\begin{array}{c}\text { Abs. } \\
\text { Freq. } \\
\left(\mathbf{f}_{\text {abs }}\right)\end{array}$ & $\begin{array}{c}\text { Rel. } \\
\text { Freq } \\
(\%) \\
\end{array}$ \\
\hline 1 & $72-79$ & 71.5 & 13 & 9.63 \\
\hline 2 & $80-87$ & 79.5 & 14 & 10.37 \\
\hline 3 & $88-95$ & 87.5 & 5 & 3.70 \\
\hline 4 & $96-103$ & 95.5 & 14 & 10.37 \\
\hline 5 & $104-111$ & 103.5 & 29 & 21.48 \\
\hline 6 & $112-119$ & 111.5 & 27 & 20.00 \\
\hline 7 & $120-127$ & 119.5 & 19 & 14.07 \\
\hline 8 & $128-135$ & 127.5 & 14 & 10.37 \\
\hline Sum & & & 135 & $100 \%$ \\
\hline
\end{tabular}

The level of tendency for research into organizational commitment:

Table 5. The level of tendency for research into organizational commitment

\begin{tabular}{cllll}
\hline Class & $\begin{array}{c}\text { Class } \\
\text { Interval }\end{array}$ & $\begin{array}{c}\text { Obs. } \\
\text { Freq. }\end{array}$ & $\begin{array}{c}\text { Relative } \\
\text { Freq. }\end{array}$ & Category \\
\hline 1 & $>108$ & 81 & $60,00 \%$ & High \\
2 & $81-108$ & 46 & $34,07 \%$ & Enough \\
3 & $54-80$ & 8 & $5,93 \%$ & Less \\
4 & $<54$ & 0 & $0 \%$ & Low \\
\hline & Sum & $\mathbf{1 3 5}$ & $\mathbf{1 0 0 \%}$ & \\
\hline
\end{tabular}

The level of tendency for research into organizational culture:

Table 6. The level of tendency for research into organizational culture

\begin{tabular}{cllll}
\hline Class & \multicolumn{1}{c}{$\begin{array}{c}\text { Class } \\
\text { Interval }\end{array}$} & $\begin{array}{c}\text { Obs. } \\
\text { Freq. }\end{array}$ & $\begin{array}{c}\text { Relative } \\
\text { Freq. }\end{array}$ & Category \\
\hline 1 & $>13$ & 54 & $40,00 \%$ & High \\
2 & $84-113$ & 55 & $40,74 \%$ & Enough \\
3 & $56-83$ & 24 & $17,78 \%$ & Less \\
4 & $<56$ & 2 & $1,48 \%$ & Low \\
\hline & Sum & $\mathbf{1 3 5}$ & $\mathbf{1 0 0} \%$ & \\
\hline
\end{tabular}

The level of tendency for research into principal leadrship:

Table 7. The level of tendency for research into principal leadrship

\begin{tabular}{cllll}
\hline Class & $\begin{array}{l}\text { Class } \\
\text { Interval }\end{array}$ & $\begin{array}{l}\text { Obs. } \\
\text { Freq. }\end{array}$ & $\begin{array}{l}\text { Relative } \\
\text { Freq. }\end{array}$ & Category \\
\hline 1 & $>113$ & 69 & $51,11 \%$ & High \\
2 & $84-113$ & 55 & $40,74 \%$ & Enough \\
3 & $56-83$ & 11 & $8,15 \%$ & Less \\
4 & $<56$ & 0 & $0 \%$ & Low \\
\hline & Sum & $\mathbf{1 3 5}$ & $\mathbf{1 0 0 \%}$ & \\
\hline
\end{tabular}

The level of tendency for research into job satisfaction:

Table 8. The level of tendency for research into job satisfaction

\begin{tabular}{cllll}
\hline Class & $\begin{array}{l}\text { Class } \\
\text { Interval }\end{array}$ & $\begin{array}{l}\text { Obs. } \\
\text { Freq. }\end{array}$ & $\begin{array}{l}\text { Relative } \\
\text { Freq. }\end{array}$ & Category \\
\hline 1 & $>108$ & 68 & $50,37 \%$ & High \\
2 & $81-108$ & 54 & $40,00 \%$ & Enough \\
3 & $54-80$ & 13 & $9,63 \%$ & Less \\
4 & $<54$ & 0 & $0 \%$ & Low \\
\hline
\end{tabular}




\begin{tabular}{lllll}
\hline Class & $\begin{array}{l}\text { Class } \\
\text { Interval }\end{array}$ & $\begin{array}{l}\text { Obs. } \\
\text { Freq. }\end{array}$ & $\begin{array}{l}\text { Relative } \\
\text { Freq. }\end{array}$ & Category \\
\hline & Total & 135 & $100 \%$ & \\
\hline
\end{tabular}

\subsection{Research Hypothesis}

\subsubsection{First Hypothesis}

Test calculation criteria obtained by the results of the magnitude of the path coefficient $\rho 31=0,18$, then $\mathrm{t}$ test. Ha accepted if thitung $>$ ttabel, the opposite if thitung $<$ ttabel so that Ho accepted. From the calculations that have been made, the values obtained thitung $=2,30$, while ttabel $=1,656$ and $\alpha=0,05$ as big as 1,656 . Therefore thit $>\operatorname{tab}(2,30>1,656)$, so that Ho refused and $\mathrm{Ha}$ accepted, which means the path coefficient is significant and proven. So, organizational culture has a positive direct effect on job satisfaction in Sibolga City Public Vocational School.

\subsubsection{Second Hypothesis}

Test calculation criteria obtained by the results of the magnitude of the path coefficient $\rho 32=0,42$, then $t$ test. Ha accepted if thitung $>$ ttabel, and opposite if thitung $<$ ttabel so Ho accepted. From the calculations that have been made, the values obtained thitung $=6,36$, while ttabel $=1,656$ and $\alpha=0,05$ as big as 1,656 . Therefore thit $>\operatorname{ttab}(6,36>1,656)$, so that Ho refused and Ha accepted, which means the path coefficient is significant and proven. So, principals' leadership has a direct positive effect on job satisfaction in Sibolga City Public Vocational School.

\subsubsection{Third Hypothesis}

Test calculation criteria obtained by the results of the magnitude of the path coefficient $\rho 41=0,23$, then $\mathrm{t}$ test. Ha accepted if thitung $>$ ttabel and opposite if thitung $<$ ttabel so Ho accepted. From the calculations that have been made, the values obtained thitung $=3,22$, while ttabel $=1,656$ and $\alpha=0,05$ as big as 1,656 . Therefore thit $>\operatorname{ttab}(3,22>1,656)$, so Ho refused and $\mathrm{Ha}$ accepted which means the path coefficient is significant and proven. So, organizational culture has a positive direct effect on organizational commitment in Sibolga City Public Vocational School.

\subsubsection{Fourth Hypothesis}

Test calculation criteria obtained by the results of the magnitude of the path coefficient $\rho 42=0,23$, then $\mathrm{t}$ test. Ha accepted if thitung $>$ ttabel and opposite if thitung $<$ ttabel so Ho accepted. From the calculations that have been made, the values obtained thitung $=3,02$, while ttabel $=1,656$ and $\alpha=0,05$ as big as 1,656 . Therefore thit $>\operatorname{ttab}(3,02>1,656)$, so Ho Ho refused and $\mathrm{Ha}$ accepted which means path coefficients are significant and proven. So, principals' leadership has a direct positive effect on organizational commitment in Sibolga City Public Vocational School.

\subsubsection{Fifth Hypothesis}

Test calculation criteria obtained by the results of the magnitude of the path coefficient $\rho 43=0,24$, then $t$ test. Ha accepted if thitung $>$ ttabel and opposite if thitung $<$ ttabel so Ho accepted. From the calculations that have been made, the values obtained thitung $=3,12$, while ttabel $=1,656$ and $\alpha=0,05$ as big as 1,656 . Therefore thit $>$ ttab $(3,12>1,656)$, so Ho Ho refused and $\mathrm{Ha}$ accepted which means path coefficients are significant and proven. So, job 
satisfaction has a positive effect on organizational commitment in Sibolga City Public Vocational School.

\subsection{Discussion of Research Results}

There are 5 hypotheses tested with Path Analysis. The five hypotheses have proven true.

\subsubsection{Organizational Culture (X1) Direct Effect on Job Satisfaction (X3)}

Based on the results of research that has been carried out there is the influence of organizational culture with job satisfaction where the magnitude of the effect is large (path coefficient between X1 with X3 $(\rho 32)=0.18$ with a large of $3 \%)$.

\subsubsection{Principal Leadership (X2) Direct Effect on Job Satisfaction (X3)}

Based on the results of the research that has been carried out there is the influence of the principal's leadership with job satisfaction where the amount of influence is large (the path coefficient between X2 and X3 $(\rho 32)=0.42$ with a large $18 \%)$.

\subsubsection{Organizational Culture (X1) Affects Directly on Organizational Commitment (X4)}

Based on the results of the research that has been done there is an influence of organizational culture with organizational commitment where the influence is large (path coefficients between X1 and X4 $(\rho 41)=0.23$ or $5 \%)$.

\subsubsection{Principal Leadership (X2) Influences Directly on Organizational Commitment (X4)}

Based on the results of the research that has been done there is the effect of job satisfaction with organizational commitment where the magnitude of the effect is equal (path coefficient between X2 and X4 $(\rho 42)=0.23$ or $5 \%)$.

\subsubsection{Job Satisfaction (X3) Influences Directly on Organizational Commitment (X4)}

Based on the results of the research that has been carried out there is an influence of job satisfaction and organizational commitment where the amount of influence is large (the path coefficient between X3 and X4 $(\rho 43)=0.24$ or $6 \%$.

\subsection{Research Limitations}

This study only explains the influence of organizational culture, principals' leadership, and job satisfaction on teacher organizational commitment to the State Vocational Schools in Sibolga City, so research needs to be conducted with a wider sample size, to be generalized in general.

In making a scientific work, many stages and processes must be carried out. As a scientific work, this research is carried out as well as possible in accordance with the procedures of scientific work. However, it is realized that the results obtained are still lacking as a result of existing limitations, resulting in results that are not fully in line with expectations.

In this study the data obtained was only through filling out questionnaires and observations given to respondents who were selected for the four variables. The research instruments distributed to respondents were only conducted one trial, based on valid and reliable statistical calculations, therefore the weakness of the instruments used still remained. In addition, respondents may not really fill in or complete the research questionnaire provided so that the answers given do not reflect the actual results. Limitations in this study will provide 
opportunities for advanced researchers who will continue and test other factors related to organizational commitment

\section{Conclusion}

Some conclusions can be taken as follows:

a. There is a positive direct effect between organizational culture (X1) on job satisfaction (X3)

b. There is a positive direct influence between principals' leadership (X2) on job satisfaction (X3).

c. There is a positive direct influence between organizational culture (X1) on organizational commitment (X4).

d. There is a positive direct influence between principals' leadership (X2) on organizational commitment (X4).

e. There is a positive direct effect between job satisfaction (X3) on organizational commitment (X4).

\section{Implications}

Based on the conclusions described above, the implications will be as follows:

(1) Efforts to increase organizational commitment through organizational culture.

(2) Efforts to increase organizational commitment through the leadership of the principal.

(3) Efforts to increase organizational commitment through teacher job satisfaction.

(4) Efforts to increase organizational commitment through organizational culture, principals' leadership and job satisfaction.

\section{Suggestions}

Based on the research findings, the following suggestions are proposed to increase teacher organizational commitment, namely:

(1) The principal should:

(a) Maintain a good and conducive school atmosphere by creating conditions of mutual respect, respect, between the teacher and the principal, between the teacher and the school community and being able to create a sense of belonging to the school, and by providing clear and fair tasks, reward and legal relationships surely, participation in decision making, pressure on achievement, pressure on training and development, security in carrying out tasks, openness of recognition and feedback, teacher enthusiasm in teaching.

(b) Involving teachers in finding solutions to problems that are being faced by schools and providing equal opportunities for teachers to develop themselves. 
(2) Teachers should:

(a) Build cooperation, open communication, and harmonious relationships for fellow teachers, so that if one teacher faces difficulties can be discussed and resolved together and always think positively about the criticisms and suggestions given by the principal and fellow teachers.

(b) Teachers must increase their knowledge and understanding of work motivation, job satisfaction which in essence is the internal condition of a teacher who encourages him to achieve an achievement or success by always actively developing himself, adding insight and knowledge to support his work in learning, sharing new experiences and information on matters that support PBM activities and build empathy and solidarity with others.

(3) Government (The education office) should:

(a) Support and provide equal opportunities for teachers to develop themselves such as providing opportunities for teachers to continue their education to a higher level.

(b) Routine conduct activities that aim to improve teacher abilities

(c) Give rewards to teachers who excel, as motivation for the teacher concerned and for other teachers.

(4) For other researchers, further research is needed on this research with different variables that influence the organizational commitment of the teacher, given the limitations in conducting research and the results obtained are not maximal.:

\section{References}

[1] Engkoswara, Lembaga Pendidikan sebagai Pusat Pembudayaan, 1st ed. Bandung: Yayasan Amal Keluarga, 2002.

[2] K. \& S. L. Schatz, Managing by Influence. New Jersey: Prentice Hall International Inc, 1995.

[3] F. Luthans, PerilakuOrganisasi. Yogyakarta: Penerbit Andi, 2006.

[4] L. \& W. Colquitt, Organizational Behavior. New York: McGraw-Hill, 2009.

[5] et al Ambarita, Biner, Perilaku organisasi. Bandung: Alfabeta, 2014.

[6] I. A. Brahmasari, "Pengaruh Variabel Budaya Perusahaan terhadap Komitmen Karyawan dan Kinerja Perusahaan Kelompok Penerbitan Pers Jawa Pos,” Disertasi Univ. Air Langga, 2004.

[7] H. T. Koesmono, "Pengaruh Budaya Organisasi Terhadap Motivasi dan Kepuasan Kerja serta kinerja Karyawan Pada Sub Sektor Industri Pengolahan Kayu Ekspor di Jawa timur," Disertasi. Univ. Airlangga,Surabaya, 2005.

[8] P. Tika, Budaya Organisasi dan Peningkatan Kinerja Perusahaan. Jakarta: PT. Bumi Aksara, 2006.

[9] A. Brahmasari, I.A, \& Suprayetno, "Pengaruh Motivasi Kerja, Kepemimpinan Dan Budaya Organisasi Terhadap Kepuasan Kerja Karyawan Serta Dampaknya Pada Kinerja Perusahaan (Studi Kasus Pada Pt. Pei Hai International Wiratama Indonesia)," J. Manaj. Dan Kewirausahaan, vol. 10, no. 2, pp. 124-135, 2008. 